\title{
食道癌患者に認められた化学薬品が原因と 考えられる抗赤血球自己抗体と輸血
}

\begin{tabular}{|c|c|c|c|c|}
\hline & & 関西医科大学 輸血部 & & \\
\hline 久保 & 進 & 石 田 萠 子 & 長”田 & 和 \\
\hline 小 西 & 寿 & 安 永 幸二郎 & & \\
\hline
\end{tabular}

関西医科大学外科学教室

光 吉一弘 山本政 勝

（昭和 59 年 8 月 22 日受付）

索引用語 : 化学薬品 (フッ化水素酸, 塩酸, 硫酸), 抗赤血球自己抗体, 食道癌, 輸血

はじめに

免疫性溶血性貧血は，先天性溶血性賀血に次いで多 く，溶血性資血の $27.6 \%$ を占め，そのなかでも温式抗体 による自己免疫性溶血性貿血（AIHA）が23.4\%と最も 多い1)。しかし，このうちの13.7\%は続発性のものであ り，基礎疾患としては SLE が最も多くて過半数を占 め, そのほかにリンパ系悪性腫湯などにも合併する4). 次いで日常繁用される $\alpha$ ーメチルドーパ，ペニシリン采 や七フロ系薬戍による免疫性溶血性貧血が溶血性貧血の $2.8 \%{ }^{1)}$ ，免疫性溶血性貧血の $3.3 \%$ 占め，その大きな 要因の一つとなっている. しかし， $\alpha$-メチルドーパで みられるごとく，これらの薬剤投与に伴う抗グロブリン 試験（クームス試験）の陽性化頻度は，溶血性貧血の発 生頻度よりさらに高いものと考えられる 2) 5). けれど も, 硫酸, 塩酸, フッ化水素酸などのような化学物質の 影響によりこのような病態を発生しうるかどうかについ ての記載は全くみられない。

一方, 肺癌, 卵巣癌や腎癌などに抗グロブリン試験陽 性の溶血性資血を合併することも報告されている6).

今回, われわれは, 硫酸, 塩酸, フッ化水素酸などの 化学薬品が原因と考えられる食道癌患者に強い IgG 型 の抗亦血球自己抗体を検出し, 手術に際して合計11単位 の赤血球輸血を施行した症例を経験したので，この自己 抗体の性状抢よび輸血に伴う経過について報告する.

症例

患 者: Y. Y., 54歳, 男性, 家屋清掃業.

主 訴 : 嚥下困難, 食物の停滞感.

家族歴：両親が高血圧. それ以外には特記すべきこと はない。
既往歴：30歳時に高血圧を指摘されるも放置し，常用 薬削の服用歴はない４6歳時肝炎に罹患する，輸血歴は ない.

現病歴：洗浄凨, 漂白鼡として, 硫酸, 塩酸, フッ化 水素酸を 20 年来使用しており，これら薬品の至適濃度を 呫で味わうことにより調整していた. 昭和58年 1 月頃か ら苲下困難, 食物の停滞感に気付くも放置, それ以後そ の程度が増強し， 1 力月間に約 $5 \mathrm{~kg} の$ 体重減少を認めた ため本院外科を受診，食道造影（Photo. 1)，内視鏡所 見ならびに生検結果（squamous cell carcinoma）から食 道癌と診断され，手術療法を目的として同年 4 月 22 日入 院となる，1 日 5 合の飲酒と，同約 3 本の喫煙を㖺む.

入院時現症: 身長 $156 \mathrm{~cm}$, 体重 $52.0 \mathrm{~kg}$, 栄養状態 正, 体温 $36.2^{\circ} \mathrm{C}$, 血圧 $170 / 90 \mathrm{~mm} \mathrm{Hg}$, 脈拍 $86 /$ 分, 正, 呼吸 10回/分, 呼吸困難 $(-)$, 皮虎 貧血 $(-)$, 黄疸 $(-)$, 眼 瞼結膜 軽度の資血 $(+)$, 黄㾝 $(-)$, 心肺異常なし, 腹 部 左季肋部に圧痛 $(+)$, 脾腫 $(-)$, 頸部リンパ節な ど触知せず。

入院時検查成辚 (Table 1) : 赤血球数 $378 \times 10^{4} / \mathrm{mm}^{3}, \mathrm{Ht}$ $34.8 \%$ と軽度の筫血を認めるも，S-Fe が44 $r / d \ell$ と低下 し，網状赤血球数 $(11 \%)$ や間接ビリルビン $(0.7 \mathrm{mg} / d \ell)$ の増加はなく, 血清ハプトグロビンも正常 $(238 \mu \mathrm{g} / \mathrm{d} \ell)$ であった。また赤血球浸透圧抵抗試験（CPC 法）は正 常，自己溶血試験，砂糖水試験はいずれも陰性であった ことから，溶血性筫血ではなく鉄欠乏性貧血と考えられ た. 免疫学的検查では, LE テスト, 抗核抗体や DNA テストは全て陰性であったが，IgG，IgA の増加ならび に直接および間接抗グロブリン試験が陽性を示した. 直 接抗グロブリン試験の結果（Table 2）は，広範囲抗グ 


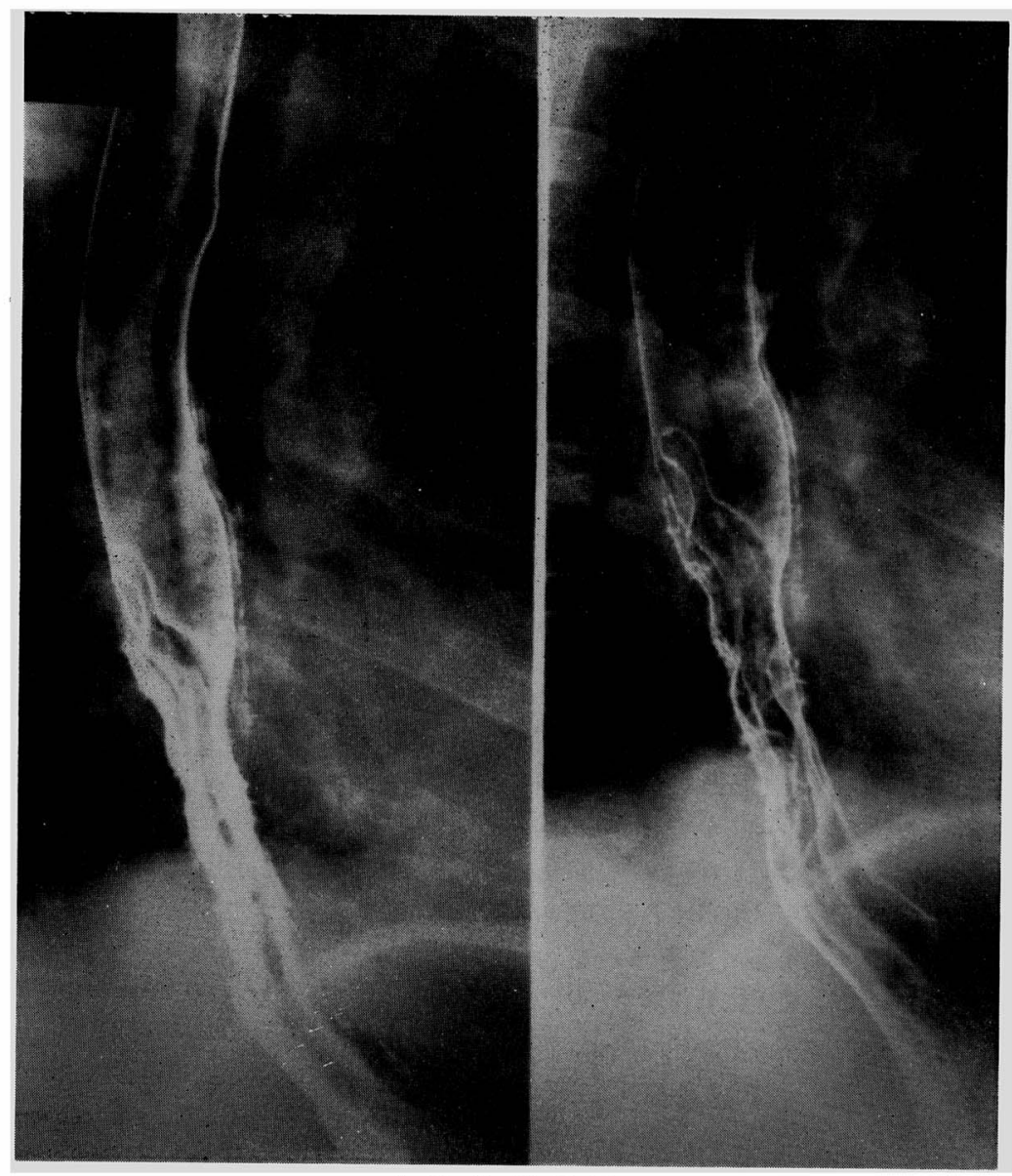

食道造影所見

Photo. 1 
ロブリン血清, 抗 IgG 血清に陽性であったが, 抗 補体血清では陰性であった. IgG サブクラスは $\mathrm{IgG}_{1}$ にのみ解離溶液で弱い活性を示した．患者の血液型は Table 3 亿示す如くであり, 血清中にす 0 型 panel cellおよびO型 - D - cell の全てに弱い反応を示す抗体が 存在したが, Rh null cell との反応を試みることができ ず，その血液型特異性注証明できなかった。この抗体は chloroquine 解離後の自己血球で全て吸収され，同種抗 体の共存は認められなかった。この自己抗体の反応状態 を Table 4 亿示す.これらの結果から，本例の抗体 産生機序は， $\alpha$-メチルドーパでみられるのと同様な自 己免疫型のものと考えられた．末梢血リンパ球のサブセ ットについては, T cell 86\%, B cell 4\%, IgG-FcR （+） T cell 20\%と異常はみられなかった。 また HLAB7 は陰性であった。
臨床経過ならびに輁血の効果（Figure 1)：貧血のた ぬに術前輸血が必要となり，昭和58年 5 月 17 日に A 型赤 血球濃厚液 (CRC) 60 铎試験的に輸血したが, 副作用 が何ら認められなかったため，引き続き29日にやはりA 型CRC 360 m を輸血した. 輸血後には赤血球数, $\mathrm{Hb}$ 值 の増加がみられ，また副作用を考えさせるような検查值 の異常や臨床症状は全く認められなかった．そこで同年 5 月31日の手術時に $600 \mathrm{~m} \ell$, 翌日には $360 \mathrm{~m} l の \mathrm{~A}$ 型 $\mathrm{CRC}$ を輸血したが，この時には赤血球数， $\mathrm{Hb}, \mathrm{Ht}$ 值は上昇 せずまた GOT, GPT, ALP および間接ビリルビン 值の上昇がみられたが，これらの値は約 2 週間後には元 に戻った. このことから, 出血量との相殺ということむ あるが，輸血の効果には乏しく，血管外溶血反応を起こ していた可能性が示唆された。しかし, 悪寒戦槚, 発 熱，黄疾や腎障害などの症状は認められなかった。その

Table 1 Laboratory Findings

\begin{tabular}{|c|c|c|c|}
\hline RBC & $+378 \times 10^{4}$ & GOT & $29 \mathrm{IU} / \mathrm{l}$ \\
\hline $\mathrm{Hb}$ & $17.6 \mathrm{~g} / \mathrm{dl}$ & GPT & $22 \mathrm{IU} / \mathrm{l}$ \\
\hline $\mathrm{Ht}$ & $\$ 34.8 \%$ & ALP & $\uparrow 330 \mathrm{lU} / \ell$ \\
\hline WBC & $11.3 \times 10^{3} / \mathrm{cmm}$ & LAP & $81 \mathrm{IU} / \mathrm{l}$ \\
\hline N. Band & $8.5 \%$ & BIL-T & $0.9 \mathrm{mg} / \mathrm{dl}$ \\
\hline Seg & $76.0 \%$ & BIL-D & $0.2 \mathrm{mg} / \mathrm{dl}$ \\
\hline Eosino & $0.5 \%$ & LDH & $223 \mathrm{IU} / \ell$ \\
\hline Lympho & $9.0 \%$ & rGTP & $84 \mathrm{IU} / \ell$ \\
\hline Mono & $6.0 \%$ & UN & $18 \mathrm{mg} / \mathrm{dl}$ \\
\hline Atypi. Lym & $0.5 \%$ & CRTN & $0.7 \mathrm{mg} / \mathrm{dl}$ \\
\hline Reticulo & $11 \%$ & UA & $5.5 \mathrm{mg} / \mathrm{dl}$ \\
\hline Platelet & $121 \times 10^{3} / \mathrm{cmm}$ & BUN & $13 \mathrm{mg} / \mathrm{dl}$ \\
\hline $\lg G$ & $\uparrow 2283 \mathrm{mg} / \mathrm{dl}$ & $\mathrm{Na}$ & $138 \mathrm{mEq} / \mathrm{\ell}$ \\
\hline $\lg A$ & T $558 \mathrm{mg} / \mathrm{dl}$ & $\mathrm{K}$ & $3.7 \mathrm{mEq} / \ell$ \\
\hline $\lg M$ & $232 \mathrm{mg} / \mathrm{dl}$ & $\mathrm{Cl}$ & $105 \mathrm{mEq} / \mathrm{\ell}$ \\
\hline T. Protein & $6.8 \mathrm{~g} / \mathrm{dl}$ & Direct Antiglobulin & test $(\mathrm{H})$ \\
\hline$A / G$ & 0.78 & Indirect Antiglobulin & $n$ test $(+)$ \\
\hline Albumin & $2.99 \%$ & & \\
\hline$\alpha_{1}$-Globulin & $0.34 \%$ & Cold agglutinin & $(\times 4)$ \\
\hline$\alpha_{2}-$ & $0.75 \%$ & ANA test & $(-)$ \\
\hline$\beta-$ & $0.90 \%$ & DNA test & $(-)$ \\
\hline$\gamma \cdot$ & $1.78 \%$ & LE test & $(-)$ \\
\hline
\end{tabular}


Table 2 Direct Antiglobulin Test

Polyspecific

Antiglobulin Serum

(+1)

Monospecific

Antiglobulin Serum

$\begin{array}{rr}\text { Anti-lgA } & (-) \\ \text { IgM } & (-) \\ \text { IgG } & (+1) \\ \text { C3 } & (-) \\ \text { C4 } & (-)\end{array}$

\section{IgG Subclass}

(1984. Jan)

$\begin{array}{rcc} & \text { Direct } & \text { Eluate } \\ \text { IgG 1 } & (-) & (+) \\ 2 & (-) & (-) \\ 3 & (-) & (-) \\ 4 & (-) & (-)\end{array}$

Table 3 Blood Group Antigens *

(1983. May)

\begin{tabular}{|l|l|}
\hline ABO & A \\
\hline Rh-Hr & CCDee \\
\hline MNSs & MNss \\
\hline Lewis & Le $(a-b+)$ \\
\hline P & $P_{1}$ \\
\hline Duffy & Fy $(a+b-)$ \\
\hline Diego & Di $(a-b+)$ \\
\hline Kidd & JK $(a-b+)$ \\
\hline Kell & kk \\
\hline Lutheran & Lu $(a-b+)$ \\
\hline Xg & Xg $(a-)$ \\
\hline
\end{tabular}

茨 クロロキン解離後の赤血球を用いて判定した

Table 4 Reactivities of Autoantibody

\begin{tabular}{|c|c|c|c|c|c|}
\hline \multirow{3}{*}{$\begin{array}{l}\text { Method } \\
\text { Saline }\end{array}$} & \multirow{3}{*}{$\begin{array}{l}\text { Incubation } \\
\text { RT 10min }\end{array}$} & \multicolumn{4}{|c|}{ Reaction } \\
\hline & & \multicolumn{2}{|c|}{ Serum } & \multicolumn{2}{|c|}{ Eluate $* 1$} \\
\hline & & $(-)$ & & $(-)$ & \\
\hline Albumin & $37^{\circ} \mathrm{C} 20 \mathrm{~min}$ & $(-)$ & & $(-)$ & \\
\hline Coombs & & $(+)$ & Panagglutinin & (冊) & Panagglutinin $\begin{array}{r}32 \\
2\end{array}$ \\
\hline Bromeline & $37^{\circ} \mathrm{C} \quad 15 \mathrm{~min}$ & $(-)$ & & $(-)$ & \\
\hline Ficin & $37^{\circ} \mathrm{C} \quad 15 \mathrm{~min}$ & $(-)$ & & $(-)$ & \\
\hline Coombs & & $(+)$ & Panagglutinin & (冊) & Panagglutinin \\
\hline
\end{tabular}


Fig. 1 CLINICAL COURSE

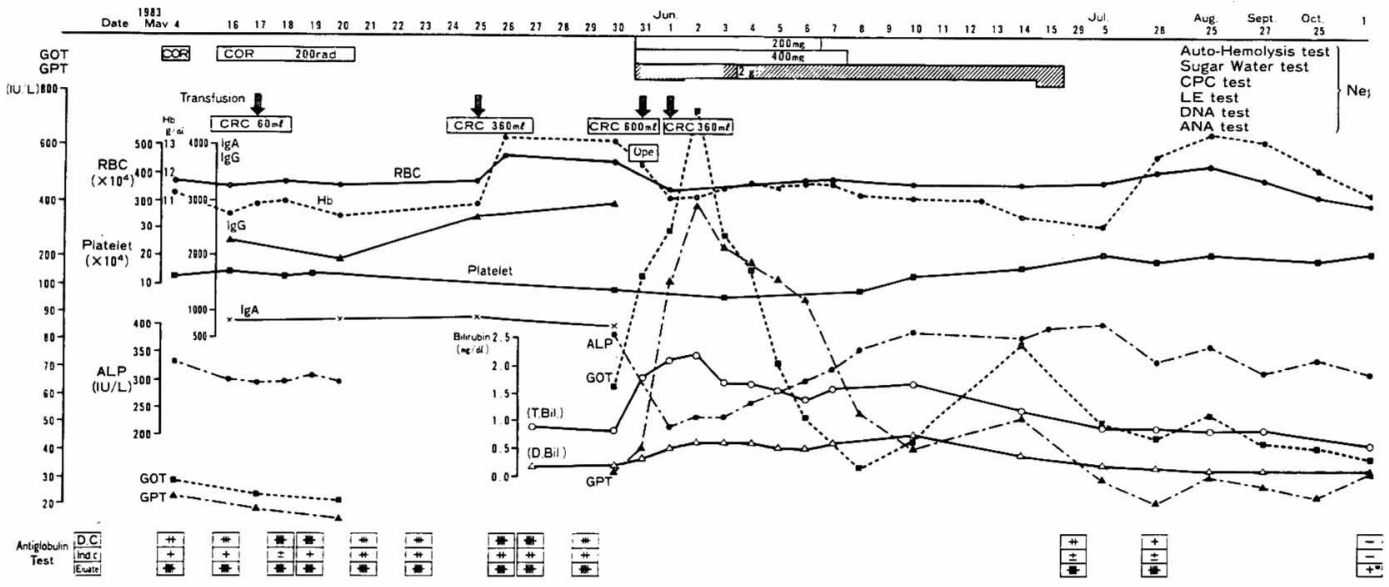

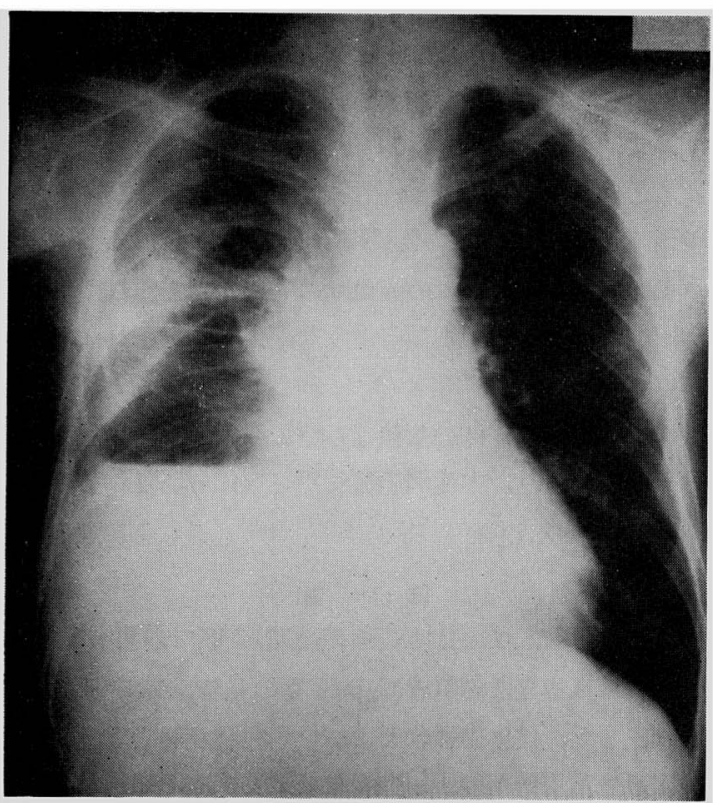

食道癌の再発，肺転移時の胸部 $\mathrm{X}$ 線写真

Photo. 2

後一旦退院し，外来で経過観察していたが，昭和59年 2 月末頃から息切れ之咳嗽気付くようになり，胸部X線 写真 (Photo. 2) で右側胸水貯溜を認めたため再入院と なる。その時の抗体検査では，血清中の抗体浍性とな り, また解離液中の抗体の反応子弱陽性と減弱してい た. なお，前回入院時から今回の入院までの約 10 力月間 は, 上記化学薬品を全く使用していなかった.
考索

薬剂䎲よる免疫性溶血性賏血は, 前述の如く全溶血性 貧血の $2.8 \%{ }^{1)}$, 免疫性溶血性貧血の $3.3 \%$ ）占め, こ とにその原因薬郕には, 日常よく用いられる $\alpha$-メチ ルドーパやペニシリン系, セフェム系抗生物質をはじめ として実に多くのものが知られている5)。また，こ秃ら の薬戍は溶血性貧血を起こさないまでも，それ以上の頻 度で抗グロブリン試験陽性の原因となり, 輸血前検査と してこのような結果が出た場合には, 適合血の選択に迷 うこともある.例えば $\alpha$ ーメチルドーパでは投与例の 6.0\%，ペニシリン系薬剂では $11.1 \%$ ，七ファロスポリ ン系薬郕では $15.0 \%$ に抗グロブリン試験の陽性化が認め られている2)。しかし実際溶血性貧血の夕られるの は， $\alpha$ ーメチルドーパでは服用者の $1 \%$ 位, あるい流 グロブリン試験陽性例の約 $0.1 〜 0.2 \%$ ある5) 10).

しかし，このような薬戍による抗グロブリン試験の陽 性化, あるい治疫性溶血性貧血の発現機序にはいくつ かの型がある5７１10).第 1 の機序は， $\alpha$-メチルドーパに 代表される最も通常的な自己抗体型で, 患者自身の赤血 球および他の多くの正常赤血球と in vitro で, 薬剤の添 加なくしても反応する抗赤血球自己抗体の形成である. この抗体注補体非結合性の IgG 不完全温式抗体が大部 分であり，血清あるいは抗体解離液には血液型既知の panel cell のいずれとも凝集する panagglutinin の性質 がみられ，大部分が抗 $\mathrm{e}$, 抗 $\mathrm{c}$ などの $\mathrm{Rh}$ 特異性をる つととが報告されているが，そうでないものもある。こ のような性質注, 特発性自己免疫性溶血性貧血 (AIHA) 
で見出される抗体のそれと同じである. 第 2 の機序は, セフェム系抗生物質でみられる非特異型で，これらの薬 剂により赤血球膜に化学的修飾が起こり，ここに非特異 的に沢山の蛋白が吸着するものである. 第 3 の機序は, ペニシリン系薬剤でみられるハプテン結合型で, 薬威が 赤血球膜と強固に結合し, 薬剂に対する抗体がこの膜表 面で薬郕と結合して抗体感作赤血球を生じるものであ る. 第 4 の機序は, キニン, キニジンおよびフェナセチ ンなどでみられる免疫複合体型で, 薬剤とその特異抗体 によって形成された免疫複合体が赤血球膜に付着して補 体活性を高めるものである。自験例にみられた抗体は IgG であり，抗補体血清による直接抗グロブリン試験が 陰性, 薬剂の添加なしの間接抗グロブリン試験が陽性, 解離液でも強い反応がみられ，乙れは自己亦血球で完全 に吸収されたことから，第1の機序，すなわち自己抗体 型と考えられる. この場合には，リウマチ因子や抗核抗 体などのほかの自己抗体の出現する頻度もやや高いが 2)，本例ではこれらは全て陰性であった。 なお本例では 高血圧がみられたが， $\alpha$ メチルドーパなどの降圧剤を 常用したことはなかった.

一方, 肺癌, 卯巣癌や腎癌などに抗グロブリン試験陽 性の溶血性䞄血を稀ではあるが合併することがある、し かしこの場合は, 癌疾患の消長, とくに外科的切除の成 否と免疫性溶血の消長とが平行する6). しかし, 本例は 食道癌に合併した抗亦血球自己抗体湯性例であるが，手 術より約 9 力月後の再発時には血清中の抗体がきしろ陰 性となり，また解離夜中の抗体の反応性も減弱している ことから，食道癌が自己抗体産生の原因になったとは考 え難い. また抗癌剤である cisplatin (cis-diamminedichloroplatinum）でも免疫性溶血を起こしうるが，本例で は使用されていないし，またこの場合はハプテン結合型 の機序である8).

一方，本例の患者が 20 年間もの長期間にわたって少量 ずつではあるが経口暴露してきた硫酸, 塩酸, フッ化水 素酸などの化学薬品は, いずれも粘膜の刺激, 腐蝕あ るい潰瘍形成作用を有しており，催腫陽性に関する明 確な記載はないが9)，これらの薬品による食道粘膜への 慢性刺激が，多量の飲酒歴とともに，十分に食道癌の原 因になり得たものと考えられる. またこれらの化学薬品 が，抗赤血球自己抗体産生の原因になり得るという報告 は見当たらないが，本例では，自己免疫疾患などの基礎 疾患や常用薬剂もなく, これらの化学薬品との接触がな くなってから約 10 力月後には, 食道癌の肺転移, 再発に
もかかわらず，またステロイド戍などによる治療をしな くても抗赤血球自己抗体が陰性化もしく海減弱化してい ることから,やはり $\alpha$ メチルドーパでもその服用中止 により 4 〜 18力月で抗グロブリン試験が陰性化する10) ということもあり, 硫酸, 塩酸, フッ化水素酸の化学薬 品のいずれかが，あるいはいずれかの組み合わせが本例 における自己抗体産生の原因となっていた可能性が考え られる、 $\alpha$-メチルドーパによる抗亦血球自己抗体の産 生機序については，抗核抗体などのほかの自己抗体の出 現を伴うこともあることから，HLA-B7 11) どの個体 側の要因とともに，これらの薬剤が免疫機構に直接作用 して自己抗原に対する免疫宽容の破綻をきたす結果で はないかとも考えられている511)。しかし本例では HLA-B7 陰性であり，ほかの自己抗体も全て陰性で あり，またリンパ球のサブセットにも異常はみられなか った.このほかに，これらの化学薬品が赤血球膜に直接 変化を与えた結果ということも考えられるが，この点に ついても不明である.

免疫性溶血性貧血症例に対与る輸血の効果について は，臨床的経過，作業能力に若干の治療効果を認めるに すぎず，その効果も一時的で，特別な場合以外はさし控 えることが望ましいとされる ${ }^{3)}$. 本例でも，少なくとも 手術時の輸血については臨床的効果に乏しく，また検査 成績から網内采組織での赤血球の破壊が考えられたが, 臨床的には何ら問題となるような副作用はみられなかっ た.

今後, 同様な症例の蓄積ならびに公衆衛生学的立場か らの研究により, 本症例の真相がさらに解明されること が必要である.

\section{結論}

硫酸, 塩酸, フッ化水素酸の長期間 経口暴露が原因 と考えられる食道癌患者に, IgG 型の抗赤血球自己抗体 を検出した．抗体の性状および自己免疫疾患のような基 礎疾患や常用薬剤の服用歴のないこと, 臨床経過などか ら, これらの化学薬品がこの自己抗体産生の原因となっ ている可能性が考えられた，本例に対する濃厚亦血球の 輸血では，明らかな臨床的副作用は認められなかった。

本論文の要旨は，第32回日本輸血学会総会（昭和59年 6 月，仙台）で発表した.

稿を終えるに臨み，本論文の御校閲を賜った関西医科 大学公衆衛生学講座原一郎教授に媣謝致します。 


\section{引用文献}

1）三輪史朗, 野見山一生, 青木国雄, 他 : 溶血性資 血江関寸る全国疫学調查. 厚生省特定疾患溶血性 貧血調查研究班（班長：三輪史朗）昭和 51 年度 研究報告書, 5 14, 1977.

2) 三輪史朗, 恒松德五郎: 薬刘誘発性溶血性貧血の 共同調査報告. 同, 321 334, 1977.

3）野見山一生, 青木国雄, 加藤孝之, 他: 溶血性資 血汇関する疫学的研究 (6)摘脾, 輸血の治療効果 に関する検討. 同, 21〜35, 1977.

4) 小峰光博: 後天性溶血性筫血. Medical Tribune, 1980年 6 月 12 日, P. 30 31.

5）高木皇輝, 河合 忠: 薬剂の赤血球結合性と免疫 溶血反応. 日本臨桨，37，3961～3968， 1979.

6) Spira, M. A., Lynch, E.C. : Autoimmune hemolytic anemia and carcinoma-An unusual associa- tion. Ame. J. Med., 67, 753 758, 1979.

7) Swisher, S. N., Burka, E. R. : In "Hematology" edited by Williams, W. J., et al., McGraw Hill, N. Y., 605 610, 1977.

8) Getaz, E. P., Beckley, S., Fitzpatrick, J., et al. : Cisplatin-induced hemolysis. N. Engl. J. Med., 302, 334 335, 1980.

9）産業中毒便覧（増補版）（後藤稠, 池田正之, 原 一郎編), 医歯薬出版, 東京, 1981.

10）藤岡成徳：薬剂によるクームス試駼陽性溶血性筫 血. 臨床免疫, 12, 355 362, 1980.

11) Kirtland, H. H., Mohler, D. N. and Horwitz, D. A. : Methyldopa inhibition of suppressor-lymphocyte function. N. Engl. J. Med., 302, 825 832, 1980. 


\title{
（欧 文 抄 録）
}

\section{Anti-Erythrocyte Autoantibody Possibly Caused by Chemicals in A Patient of Esophageal Cancer-A Case Report}

\author{
Susumu Okubo, Tomoko Ishida, Kazuko Osada, Toshi Konishi \\ and Kojiro Yasunaga \\ Transfusion Unit of Kansai Medical University Hospital \\ Kazuhiro Mitsuyoshi and Masakatsu Yamamoto \\ Department of Surgery, Kansai Medical University, \\ Moriguchi, Osaka, Japan
}

Here reported a case of esophageal cancer showing high level of anti-erythrocyte autoantibody of IgG type possibly caused by his professional long-term exposure to chemicals such as hydrogen fluoride, chloride and sulfuric acid.

Case: Y.Y., 54 y. o., M..He had been working as a house washer over twenty years using hydrogen fluoride, chloride and sulfuric acid as cleansers and bleaching agents, used to taste the mixtures of the chemicals in order to obtain the best ratio and condition of them. As he had been quite healthy since his birth, he had never used any medicines habitually, and had never received blood transfusion. On Apr. 1983, he consulted our hospital, mainly complaining of dysphagia, and was diagnosed to be suffering from esophageal cancer (squamous cell carcinoma) by means of radiological and endoscopic examinations. Immunological tests detected high level of anti-erythrocyte autoantibody (IgG), i. e. positive direct and indirect anti-globulin tests using polyspecific and anti-IgG antiserum without addition of the chemicals, both his serum and eluate from his red cells showing panaggulutination against several panel cells of blood type $O$, and these antibodies were absorbed completely by his own red cells. None of other autoantibodies such as LE factor, anti-nuclear antibody and anti-DNA antibody were detected.

For the operation to remove his cancer, concentrated human red blood corpuscles of $960 \mathrm{ml}$ in total were transfused to him, although pretransfusion cross match tests between these CRCs and his blood yielded incompatible results. The transfusion seemed not to be sufficiently effective, and caused a slight elevation of seral GOT, GPT and indirect bilirubin, suggesting extravascular hemolysis, for about two weeks thereafter, although no remarkable clinical side effects such as fever or renal dysfunction were recognized.

About ten months after the operation, while pulmonary metastases of the cancer occurred, the anti-erythrocyte autoantibody titers in his eluate and serum went down. During these ten months, 
he had never been exposed to these chemicals.

The observation of this case suggests that a long-term oral exposure to the chemicals such as hydrogen fluoride, chloride and sulfuric acid might cause esophageal cancer, and on the other hand, it might cause production of anti-erythrocyte autoantibody. Hitherto, no papers reporting such cases as ours could be found in the literature. It should be necessary to pile up such cases, in order to provoke hygienical and experimental researches which may result the establishment of the concept of an occupational disease newly found. 